\title{
Komposisi dan Struktur Komunitas Fitoplankton di Estuari Sungai Mempawah, Kalimantan Barat
}

\author{
Muhammad Yusuf ${ }^{1 *}$, Muliadi ${ }^{1}$, Sukal Minsas² \\ 1 Program Studi Ilmu Kelautan, FMIPA, Universitas Tanjunpura, Pontianak- \\ Indonesia \\ 2 Program Studi Biologi, FMIPA, Universitas Tanjungpura, Pontianak-Indonesia \\ *Correspondence email: Muhammad Yusuf \\ $\bowtie$ ocoepblack1208@gmail.com
}

\section{Received: 04 December 2018- Accepted: 07 January 2019 \\ Published: 28 February 2019 @ Author(s) 2019. This article is open access}

\begin{abstract}
Estuari Sungai Mempawah merupakan wilayah Kalimantan Barat yang terletak di $00^{\circ} 18 ’ 21.82^{\prime \prime} \mathrm{LU}$ - 108 ${ }^{\circ} 7^{\prime} 46.65^{\prime \prime}$ BT. Estuari Sungai Mempawah berbatasan langsung dengan Laut Natuna. Estuari Sungai Mempawah dimanfaatkan oleh warga sekitar Sungai Mempawah sebagai lokasi transportasi, dermaga dan juga sebagai lokasi pembuangan limbah rumah tangga. Fitoplankton merupakan organisme yang berperan penting sebagai produsen dalam tingkatan rantai makanan, maka dari itu kelimpahan jumlah fitoplankton di suatu perairan dapat dijadikan sebagai indikator baik atau buruknya suatu perairan. Penelitian ini bertujuan untuk mengetahui komposisi dan struktur komunitas fitoplankton, kualitas lingkungan perairan dan korelasi kepadatan fitoplankton dengan parameter fisika - kimia perairan estuari Sungai Mempawah. Penelitian ini telah dilakukan mulai Oktober 2017 dengan menggunakan metode survei dan koleksi langsung dilapangan. Hasil penelitian menunjukkan Komposisi fitoplankton di estuari Sungai Mempawah terdiri dari 8 divisi, 10 kelas, 33 ordo, 40 famili dan 57 genus. Kepadatan tertinggi dari fitoplankton adalah berasal dari kelas Bacillariophyceae pada stasiun 1 sebanyak $3391 \mathrm{Ind} / \mathrm{L}$. Kisaran indeks keanekaragaman fitoplankton 2,687 - 2,958, indeks keseragaman fitoplankton 0,298 - 0,459 dan indeks dominansi 0,077-0,121. Kondisi perairan di estuari Sungai Mempawah masih dalam kondisi baik. Parameter salinitas berkorelasi positif dengan kepadatan fitoplankton di estuari Sungai mempawah $(0,894)$, sedangkan nitrat berkorelasi negatif dengan kepadatan fitoplankton di estuari Sungai Mempawah $(-0,900)$.
\end{abstract}

Keywords: Fitoplankton, struktur komunitas, estuari Sungai Mempawah

\section{Pendahuluan}

Estuari Sungai Mempawah merupakan wilayah Kalimantan Barat yang terletak di $00^{\circ} 18^{\prime} 21.82^{\prime \prime}$ LU - 108 57'46.65" BT. Estuari Sungai Mempawah berbatasan langsung dengan Laut Natuna dan Sungai Mempawah. Estuari Sungai Mempawah dimanfaatkan oleh warga sekitar Sungai
Mempawah sebagai lokasi transportasi, dermaga dan juga sebagai lokasi pembuangan limbah rumah tangga. Hal ini dapat memberikan dampak buruk pada perairan estuari Sungai Mempawah dan kelangsungan hidup organisme perairan khususnya bagi fitoplankton. Fitoplankton merupakan organisme yang berperan penting 
sebagai produsen dalam tingkatan rantai makanan, maka dari itu kelimpahan jumlah fitoplankton di suatu perairan dapat dijadikan sebagai indikator baik atau buruknya perairan tersebut (Thurman, 1994).

Penelitian fitoplankton di Kalimantan Barat telah dilakukan di estuari Sungai Peniti Kalimantan Barat yang dilakukan oleh Minsas, (2013) mendapatkan komposisi fitoplankton yang didominasi oleh kelas Bacillariophyceae sebanyak 70 genera dengan kandungan klorofil-a fitoplankton kategori rendah hingga sedang. Penelitian zooplankton di estuari Sungai Mempawah dilakukan oleh Rahayu et al., (2013) menemukan kompisisi zooplankton yang didominasi oleh filum Arthropoda sebanyak 29 genera. Namun untuk penelitian fitoplankton di estuari Sungai Mempawah belum pernah dilakukan. Maka dari itu penelitian fitoplankton ini sangat perlu dilakukan agar dapat memberikan informasi mengenai kualitas fisika, kimia dan biologi perairan di estuari Sungai Mempawah.

Penelitian ini mengkaji struktur komunitas, kepadatan, keanekaragaman fitoplankton di estuari dapat digunakan sebagai bioindikator perairan. Oleh karena itu, penelitian ini penting dilakukan mengenai keanekaragaman fitoplankton di estuari Sungai Mempawah Kalimantan Barat. Tujuan dari penelitian ini adalah untuk mengetahui komposisi, kualitas perairan dan korelasi kepadatan fitoplankton dengan parameter fisika - kimia perairan di estuari Sungai Mempawah. Manfaat dari penelitian ini untuk memberikan informasi mengenai komposisi fitoplankton serta menjadi bahan kajian lebih lanjut dalam pengelolaan dan pemanfaatan kualitas lingkungan perairan atau sebagai bioindikator di estuari Sungai Mempawah Kalimantan Barat.

\section{Metode}

\subsection{Waktu dan tempat}

Pengambilan sampel fitoplankton dilaksanakan pada bulan Oktober 2017. Pengambilan sampel fitoplankton di estuari Sungai Mempawah Kalimantan barat dan dilanjutkan di Laboratorium Ilmu kelautan Fakultas Metematika dan Ilmu Pengetahuan Alam Universitas Tanjungpura, Pontianak. Penentuan stasiun sampling fitoplankton menggunakan metode purposive random sampling dengan rona lingkungan yang berbeda. Stasiun - stasiun tersebut yaitu mulut estuari Sungai mempawah yang berhadapan langsung dengan Laut Natuna (Stasiun 1), estuari Sungai Mempawah (Stasiun 2), dermaga Sungai Mempawah (Stasiun 3), jembatan Sungai Mempawah berdekatan dengan pemukiman (Stasiun 4) dan sekitar pemukiman (Stasiun 5) (Gambar 1).

\subsection{Alat dan Bahan}

Bahan yang digunakan dalam penelitian ini

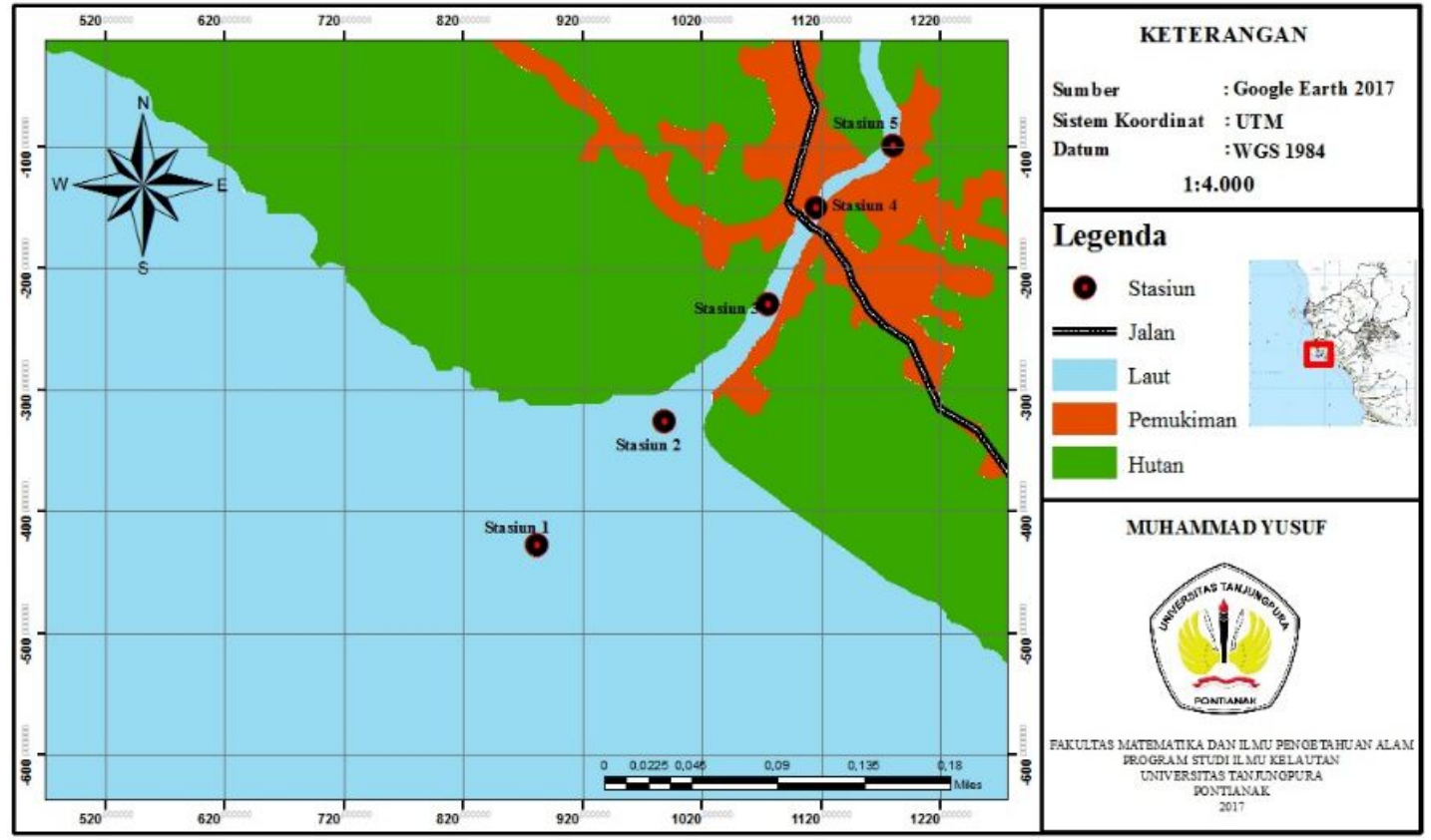

Gambar 1. Peta lokasi pengambilan sampel fitoplankton di estuari Sungai Mempawah 
adalah amilum, formalin 4\%, gliserin, H2SO4 pekat, indikator PP (Phenolpthaliein), kertas label, kertas A4 polos, KOH-KI, lakban hitam, MnSO4, metil orange, $\mathrm{Na} 2 \mathrm{~S} 2 \mathrm{O} 3$ dan $\mathrm{Na} 2 \mathrm{CO} 3$. Alat yang digunakan adalah botol flakon, botol sampel plankton, botol winkler, cool box, cover glass, ember ukuran 5L, Erlemeyer, flowmeter, objek gelas, GPS (Global Positioning System), kamera, mikroskop, $\mathrm{pH}$ meter, pipet tetes, plankton net, refraktometer secchi disk, Spuit $1 \mathrm{ml}$ dan termometer.

Pengambilan sampel fitoplankton dilakukan dengan menggunakan metode pengambilan langsung dilapangan sebanyak 3 kali pengulangan pada tepi kiri, tengah dan tepi kanan estuari Sungai Mempawah. Setiap pengulangan sampel diambil sebanyak $100 \mathrm{~L}$ dan dimasukkan ke dalam botol sampel dengan volume $20 \mathrm{ml}$ kemudian di awetkan menggunakan formalin $4 \%$ dan gliserin (Hadi, 2005). Sampel fitoplankton diamati di laboratorium menggunakan mikroskop dengan perbesaran $100 \mathrm{x}$ dan $400 \mathrm{x}$. Selanjutnya fitoplankton yang ditemukan diidentifikasi. Pengukuran parameter lingkungan adalah alkalinitas, CO2, DO, TSS, TDS dan kandungan hara seperti : nitrat, fosfat, $\mathrm{pH}$, kecerahan, suhu, arus dan salinitas.

\subsection{Analisis Data}

\subsubsection{Analisis Kepadatan Fitoplankton}

Perhitungan analisis kepadatan dan kepadatan relatife fitplankton menggunakan rumus LDMC (Lackey Drop Microtransect Counting) (APHA, 2000):

$$
F=\frac{Q_{1}}{Q_{2}} \times \frac{V_{1}}{V_{2}} \times \frac{1}{P} \times \frac{1}{W} \times N
$$

Keterangan :

$Q_{1}=$ Luas cover glass (mm2)

$Q_{2}=$ Luas lapang pandang $(\mathrm{mm} 2)$

$V_{1}=$ Volume sampel yang terkonsentrasi

(L)

$V_{2}=$ Volume sampel yang di ambil (L)

$\mathrm{N}=$ Jumlah individu yang ditemukan (ind/L)

$\mathrm{P}=$ Jumlah lapang pandang yang ditemukan (ind)

$\mathrm{W}=$ Volume air yang disaring $(\mathrm{L})$

\subsubsection{Analisis Keanekaragaman}

Analisis keanekaragaman fitoplankton menggunakan persamaan Shannon-Wiener (Krebs, 1989)

$H^{\prime}=-\sum_{i=0}^{i} p i \ln p i$

Keterangan :

$H^{\prime}=$ indeks keanekaragaman

$P_{i}=\frac{n_{i}}{N}$

$n_{i}=$ Jumlah Kepadatan Genus ke-i (ind/cm2)

$\mathrm{N}=$ Total kepadatan (ind $/ \mathrm{cm} 2)$

Menurut Krebs (1989) klasifikasi kisaran nilai indeks keseragaman sebagai berikut:

$H^{\prime}<1 \quad=$ Keanekaragaman rendah

$1<H^{\prime}<3 \quad=$ Keanekaragaman sedang

$H^{\prime}>3=$ Keanekaragaman tinggi

\subsubsection{Analisis Keseragaman}

Analisis keanekaragaman fitoplankton menggunakan persamaan Evennes (Krebs, 1989).

$E=\frac{H^{\prime}}{H_{\text {maks }}}$

Keterangan :

$\mathrm{E}=$ Indeks keseragaman (Evennes)

$H^{\prime} \quad=$ Indeks keanekaragaman

$H_{\text {maks }}=\mathrm{LnS}$

$\mathrm{S}=$ Jumlah genus yang ditemukan

Kisaran nilai indeks keseragaman adalah 0-1. Semakin kecil nilai indeks keseragasaman menunjukkan semakin kecil keseragaman populasi plankton di perairan tersebut (Krebs, 1989).

\subsubsection{Analisis Dominasi}

Analisis dominansi fitoplankton menggunakan rumus (Krebs, 1989) sebagai berikut :

$C=\sum-\left(P_{i}\right)^{2}$

Keterangan :

$\mathrm{C} \quad=$ Indeks dominansi

$P_{i}=\frac{n_{i}}{N}$

$n_{i}=$ Jumlah genus setiap spesies $(\mathrm{ind} / \mathrm{cm} 2)$

$\mathrm{N}=$ Jumlah total genus setiap spesies (ind $/ \mathrm{cm} 2$ )

Menurut Krebs (1989) kisaran nilai indeks dominansi adalah $0-1$. Jika nilai dominansi 
mencapai nilai 1, maka dinyatakan dominansi plankton di perairan tersebut sangat tinggi.

\subsubsection{Analisis Korelasi}

Koefisien korelasi parameter fisika-kimia air dengan kepadatan fitoplankton di analisis secara statistik menggunakan analisis Spearman dengan bantuan software SPSS 18.

\section{Hasil dan Pembahasan}

\subsubsection{Komposisi Fitoplankton}

Hasil identifikasi fitoplankton yang ditemukan di estuari Sungai Mempawah, Kecamatan Mempawah Hilir, Kabupaten Mempawah, Kalimantan Barat terdiri dari 8 divisi, 10 kelas, 33 ordo, 40 famili dan 57 genus. Komposisi fitoplankton pada seluruh stasiun penelitian di estuari Sungai Mempawah dapat dilihat pada Gambar 2.

Komposisi fitoplankton di estuari Sungai Mempawah ditemukan sebanyak 10 kelas yaitu Bacillariophyceae, Chlorophyceae, Cyanophyceae, Chroococcusphyceae, Chrysophyceae, Dinophyceae, Dictyochophyceae, Litosmateae, Treboxiophyceae dan Zygnematophyceae pada seluruh stasiun pengamatan. Pada seluruh stasiun kelas Bacillariophyceae memiliki jumlah yang sangat tinggi.

Tingginya kelas Bacillariophyceae ditemukan terutama pada stasiun 1 yang mengarah ke Laut Natuna. Tingginya kelas Bacillariophyceae disebabkan oleh kelas Bacillariophyceae memiliki kemampuan menyesuaikan diri terhadap kondisi lingkungan perairan disekitarnya dibandingkan dengan kelas lainnya. Menurut Arinardi et al., (1997) kelas Bacillariophyceae mampu beradaptasi dengan kondisi lingkungan sekitarnya, karena kelas
Bacillariophyceae memiliki sifat kosmopolitan dan daya adaptasi yang tinggi terhadap lingkungan sekitarnya. Nybakken (1992) menambahkan bahwa, kelas Bacillariophycea memiliki ukuran yang cukup besar, sehingga mudah terperangkap ke dalam jaring plankton. Kelompok fitoplankton yang sering dijumpai pada perairan tropis didominasi oleh kelas Bacillariophyceae dan kelas Dynophyceae (Nontji, 2008).

Hal ini serupa dengan hasil penelitian Minsas (2013), di perairan estuari Sungai Peniti Kalimantan Barat, kelas Bacillariophyceae mendominasi sebanyak 70 spesies yang ditemukan. Selain kelas Bacillariophyceae, kelas Chlorophyceae juga mendominasi di estuari Sungai Mempawah. Kelas Chlorophyceae di estuari Sungai Mempawah ditemukan cukup melimpah pada stasiun 3 hingga stasiun 5 yang mengarah ke hulu Sungai Mempawah, karena pada masing-masing stasiun tersebut nilai salinitas yang didapatkan adalah $0 \%$.

Mendominasinya kelas Chlorophyceae di estuari Sungai Mempawah perairan diduga pengaruh masuknya air tawar yang berasal dari hulu Sungai Mempawah sehingga kelompok fitoplankton yang ditemukan dominan berasal dari kelas Chlorophyceae. Serupa dengan hasil penelitian Minsas (2013), juga menemukan kelas Chlorophyceae pada muson barat sebanyak 5 spesies dengan lingkungan perairan yang memiliki salinitas > 5\%. Menurut West (1961) kelas Chlorophyceae dapat hidup pada salinitas perairan yang berkisar antara 0 $\%-8 \%$. Masuknya air tawar di estuari disebabkan oleh terjadinya pasang surut sungai, dimana saat pasang di daerah estuari sungai mendapatkan pasokan air dari arah laut sedangkan saat surut di daerah estuari

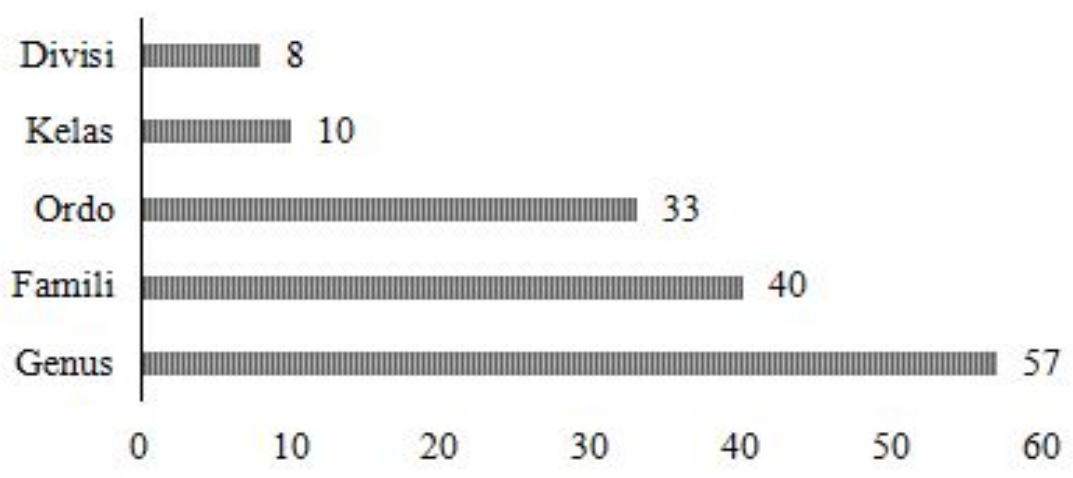

Gambar 2. Komposisi fitoplankton di estuari Sungai Mempawah 
banyak mendapatkan pasokan air dari arah hulu sungai (Nybakken, 1992).

\subsubsection{Kepadatan Relatif Fitoplankton}

Kepadatan fitoplankton di estuari Sungai Mempawah tertinggi pada stasiun 1 yaitu sebanyak $3391 \quad \mathrm{Ind} / \mathrm{L}$ dan kepadatan fitoplankton terendah pada stasiun 4 yaitu sebanyak $676.9 \mathrm{Ind} / \mathrm{L}$ dapat dilihat pada Tabel 1.

Tingginya kepadatan fitoplankton pada stasiun 1 didominasi oleh kelas

Tabel 1. Kepadatan dan Kepadatan Relatif Fitoplankton di Estuari Sungai Mempawah

\begin{tabular}{|c|c|c|c|c|c|c|c|c|c|c|}
\hline \multirow{2}{*}{ Genus } & \multicolumn{2}{|c|}{ Stasiun 1} & \multicolumn{2}{|c|}{ Stasiun 2} & \multicolumn{2}{|c|}{ Stasiun 3} & \multicolumn{2}{|c|}{ Stasiun 4} & \multicolumn{2}{|c|}{ Stasiun 5} \\
\hline & K & KR & K & KR & K & KR & K & KR & K & KR \\
\hline \multicolumn{11}{|l|}{ Bacillariophyceae } \\
\hline Amphora & 83,71 & 2,47 & 48,53 & 1,71 & 1,21 & 0,17 & 4,85 & 0,72 & 4,85 & 0.64 \\
\hline Asterionella & 10,92 & 0,32 & - & - & - & - & - & - & - & - \\
\hline Asteromphalus & 3,64 & 0,11 & 1,21 & 0,04 & 1,21 & 0,17 & - & - & 1,21 & 0,16 \\
\hline Bacteriastrum & 49,34 & 1,46 & 98,27 & 3,46 & 10,92 & 1,54 & 15,77 & 2,33 & 14,56 & 1,91 \\
\hline Bellerochea & 6,47 & 0,19 & - & - & - & - & - & - & - & - \\
\hline Biddulphia & 209,10 & 6,17 & $\begin{array}{c}181,9 \\
8\end{array}$ & 6,40 & 25,48 & 3,59 & 13,34 & 1,97 & 14,56 & 1,91 \\
\hline Campylodiscus & 2,02 & 0,06 & 1,21 & 0,04 & - & - & - & - & - & - \\
\hline Centronella & 1,62 & 0,05 & 15,77 & 0,56 & 7,28 & 1,03 & 14,56 & 2,15 & 12,13 & 1,59 \\
\hline Chaetoceros & 216,80 & 6,39 & $\begin{array}{c}161,3 \\
5\end{array}$ & 5,68 & 24,26 & 3,42 & 9,71 & 1,43 & 10,92 & 1,43 \\
\hline Corethron & 16,18 & 0,48 & 24,26 & 0,85 & 1,21 & 0,17 & - & - & - & - \\
\hline Coscinodiscus & 132,20 & 3,90 & $\begin{array}{c}403,9 \\
8\end{array}$ & 14,22 & $\begin{array}{c}132,2 \\
4\end{array}$ & 18,63 & 92,20 & $\begin{array}{c}13,6 \\
2\end{array}$ & 53,38 & 7,00 \\
\hline Cyclotella & 45,29 & 1,34 & 26,69 & 0,94 & 2,43 & 0,34 & 6,07 & 0,90 & 9,71 & 1,27 \\
\hline Cylindrotheca & - & - & 30,33 & 1,07 & 3,64 & 0,51 & 2,43 & 0,36 & 2,43 & 0,32 \\
\hline Ditylum & 245,90 & 7,25 & $\begin{array}{c}542,2 \\
9\end{array}$ & 19,09 & 38,82 & 5,47 & 48,53 & 7,17 & 66,72 & 8,74 \\
\hline Entomonies & 0,40 & 0,01 & - & - & - & - & - & - & - & - \\
\hline Eucampia & 55,00 & 1,62 & 23,05 & 0,81 & 2,43 & 0,34 & 8,49 & 1,25 & 6,07 & 0,79 \\
\hline Fragilaria & 1,62 & 0,05 & - & - & - & - & - & - & - & - \\
\hline Guinardia & 30,73 & 0,91 & 42,46 & 1,49 & 10,92 & 1,54 & 1,21 & 0,18 & 8,49 & 1,11 \\
\hline Hemiaulus & 16,18 & 0,48 & 26,69 & 0,94 & - & - & - & - & - & - \\
\hline Lauderia & 946,70 & 27,92 & $\begin{array}{c}319,0 \\
6\end{array}$ & 11,23 & 3,64 & 0,51 & 4,85 & 0,72 & - & - \\
\hline Leptocylindrus & 28,71 & 0,85 & 4,85 & 0,17 & - & - & - & - & 7,28 & 0,95 \\
\hline Licmophora & 4,04 & 0,12 & 4,85 & 0,17 & 4,85 & 0,68 & 2,43 & 0,36 & 4,85 & 0,64 \\
\hline Navicula & 12,94 & 0,38 & 36,40 & 1,28 & 3,64 & 0,51 & 9,71 & 1,43 & 6,07 & 0,79 \\
\hline Nitzschia & 82,90 & 2,45 & 12,13 & 0,43 & 21,84 & 3,08 & 19,41 & 2,87 & 26,69 & 3,50 \\
\hline Odontella & 1,62 & 0,05 & - & - & - & - & - & - & - & - \\
\hline Opephora & - & - & 1,21 & 0,04 & 1,21 & 0,17 & - & - & - & - \\
\hline Pleurosigma & 95,44 & 2,81 & $\begin{array}{c}198,9 \\
6\end{array}$ & 7,00 & 70,36 & 9,91 & 66,72 & 9,86 & 49,74 & 6,52 \\
\hline Pseudo-nitzschia & - & - & 1,21 & 0,04 & - & - & 3,64 & 0,54 & - & - \\
\hline Pseudosolenia & 31,95 & 0,94 & 20,62 & 0,73 & 6,07 & 0,85 & 3,64 & 0,54 & 2,43 & 0,32 \\
\hline Rhizosolenia & 96,24 & 2,84 & 23,05 & 0,81 & 10,92 & 1,54 & 8,49 & 1,25 & 1,21 & 0,16 \\
\hline Skeletonema & 178,30 & 5,26 & $\begin{array}{c}138,3 \\
0\end{array}$ & 4,87 & 50,95 & 7,18 & 47,31 & 6,99 & 50,95 & 6,68 \\
\hline Stauronies & - & - & - & - & - & - & 1,21 & 0,18 & 6,07 & 0,79 \\
\hline Streptotheca & 1,21 & 0,04 & 16,98 & 0,60 & 8,49 & 1,20 & 1,21 & 0,18 & 2,43 & 0,32 \\
\hline Surirella & 11,32 & 0,33 & 27,90 & 0,98 & 36,40 & 5,13 & 50,95 & 7,53 & 44,89 & 5,88 \\
\hline Thalassionema & 29,12 & 0,86 & 14,56 & 0,51 & 2,43 & 0,34 & 4,85 & 0,72 & 6,07 & 0,79 \\
\hline Thalassiosira & 467,90 & 13,80 & $\begin{array}{c}241,4 \\
2\end{array}$ & 8,50 & 40,03 & 5,64 & 77,64 & $\begin{array}{c}11,4 \\
7\end{array}$ & 74,00 & 9,70 \\
\hline Thalassiothrix & 21,84 & 0,64 & 27,90 & 0,98 & 13,34 & 1,88 & 3,64 & 0,54 & 15,77 & 2,07 \\
\hline \multicolumn{11}{|l|}{ Chlorophyceae } \\
\hline Closterium & - & - & 2,43 & 0,09 & 6,07 & 0,85 & 2,43 & 0,36 & 1,21 & 0,16 \\
\hline Coelastrum & 0,40 & 0,01 & - & - & - & - & - & - & - & - \\
\hline Cosmarium & - & - & - & - & - & - & - & - & 12,13 & 1,59 \\
\hline Euastrum & - & - & - & - & 2,43 & 0,34 & 1,21 & 0,18 & 6,07 & 0,79 \\
\hline Eudorina & 5,66 & 0,17 & - & - & - & - & - & - & - & - \\
\hline Micrasterias & - & - & - & - & 1,21 & 0,17 & - & - & 8,49 & 1,11 \\
\hline Pediastrum & 3,64 & 0,11 & 1,21 & 0,04 & 3,64 & 0,51 & 4,85 & 0,72 & 8,49 & 1,11 \\
\hline Scenedesmus & 2,02 & 0,06 & - & - & 2,43 & 0,34 & 1,21 & 0,18 & 3,64 & 0,48 \\
\hline Straurastrum & 16,58 & 0,49 & 14,56 & 0,51 & 19,41 & 2,74 & 16,98 & 2,51 & 24,26 & 3,18 \\
\hline
\end{tabular}


Tabel 1. Kepadatan dan Kepadatan Relatif Fitoplankton di Estuari Sungai Mempawah (Lanjutan)

\begin{tabular}{|c|c|c|c|c|c|c|c|c|c|c|}
\hline \multirow{2}{*}{ Genus } & \multicolumn{2}{|c|}{ Stasiun 1} & \multicolumn{2}{|c|}{ Stasiun 2} & \multicolumn{2}{|c|}{ Stasiun 3} & \multicolumn{2}{|c|}{ Stasiun 4} & \multicolumn{2}{|c|}{ Stasiun 5} \\
\hline & $\mathbf{K}$ & KR & $\mathbf{K}$ & KR & $\mathbf{K}$ & KR & $\mathbf{K}$ & KR & $\mathbf{K}$ & KR \\
\hline \multicolumn{11}{|l|}{ Trebouxiophyceae } \\
\hline $\begin{array}{l}\text { Chlorella } \\
\text { Chroococcophyceae }\end{array}$ & 1,62 & 0,05 & 3,64 & 0,13 & 6,07 & 0,85 & 12,13 & 1,79 & 16,98 & 2,23 \\
\hline Dactylococcopsis & 0,81 & 0,02 & - & - & - & - & - & - & - & - \\
\hline \multicolumn{11}{|l|}{ Zygnematophyceae } \\
\hline Staurodesmus & 14,56 & 0,43 & 59,45 & 2,09 & 100,69 & 14,19 & 83,71 & 12,37 & 158,92 & 20,83 \\
\hline \multicolumn{11}{|l|}{ Chyanophyceae } \\
\hline Oscillatoria & 3,64 & 0,11 & 7,28 & 0,26 & 3,64 & 0,51 & 4,85 & 0,72 & 9,71 & 1,27 \\
\hline \multicolumn{11}{|l|}{ Litostomatea } \\
\hline Loxophylum & 3,64 & 0,11 & - & - & - & - & - & - & 2,43 & 0,32 \\
\hline \multicolumn{11}{|l|}{ Dictyochophyceae } \\
\hline Dictyocha & 0,81 & 0,02 & 4,85 & 0,17 & 4,85 & 0,68 & 1,21 & 0,18 & 1,21 & 0,16 \\
\hline \multicolumn{11}{|l|}{ Chrysophyceae } \\
\hline Dinobryon & - & - & 3,64 & 0,13 & 2,43 & 0,34 & 13,34 & 1,97 & 3,64 & 0,48 \\
\hline \multicolumn{11}{|l|}{ Dinophyceae } \\
\hline Ceratium & 121,30 & 3,58 & 4,85 & 0,17 & 8,49 & 1,20 & 3,64 & 0,54 & 2,43 & 0,32 \\
\hline Dinophysis & 11,73 & 0,35 & 6,07 & 0,21 & 2,43 & 0,34 & 3,64 & 0,54 & - & - \\
\hline Noctiluca & 0,40 & 0,01 & - & - & - & - & - & - & - & - \\
\hline Peridinium & 67,13 & 1,98 & 15,77 & 0,56 & 9,71 & 1,37 & 4,85 & 0,72 & - & - \\
\hline $3391 \quad 100$ & 2841 & 100 & 709 & 100 & 676 & 100 & 763 & 100 & & \\
\hline
\end{tabular}

Bacillariophyceae. Hal tersebut dikarenakan kelas Bacillariophyceae memiliki kemampuan menyesuaikan diri terhadap kondisi lingkungan perairan di sekitarnya dibandingkan dengan kelas lainnya. Arinardi et al., (1997), menyatakan bahwa kebanyakkan fitoplankton di perairan pantai atau estuari yang berasal dari kelas Bacillariophycea memanfaatkan kadar zat hara lebih banyak untuk metabolisme. Selain zat hara, kondisi lingkungan yang lain juga berpengaruh terhadap kepadatan kelas Bacillariophyceae seperti: arus, salinitas, cahaya, suhu, $\mathrm{pH}$ dan kekeruhan. Kelompok fitoplankton yang dapat beradaptasi terhadap salinitas diatas 20\%o sebagian besar berasal dari kelas Bacillariophyceae (Dianthani, 2003). Genus yang mendominasi pada stasiun 1 berasal dari kelas Bacillariophicea yaitu genus Lauderia kepadatannya hingga mencapai 947 Ind/L. Tingginya kepadatan genus Lauderia juga didukung oleh kondisi lingkungan yang baik untuk pertumbuhan genus Lauderia. Salinitas pada stasiun 1 berkisar antara $15 \%$ o hingga $20.6 \%$, sangat cocok untuk pertumbuhan dan kepadatan genus Lauderia. Reigman et al., (1996), menyatakan bahwa genus Lauderia dapat tumbuh dengan baik pada kondisi perairan yang memiliki intensitas cahaya rendah dan kisaran salinitas 10\% hingga 31\%o. Genus Lauderia dapat bertahan pada perairan yang memiliki kedalaman $0 \mathrm{~m}-170 \mathrm{~m}$ dan juga dapat bertahan pada perairan yang memiliki suhu berkisar $-1,9^{\circ} \mathrm{C}$ hingga $29,4{ }^{\circ} \mathrm{C}$ (OBIS, 2011).

Kepadatan fitoplankton terendah terdapat pada stasiun 4 yaitu $676.9 \mathrm{Ind} / \mathrm{L}$. Rendahnya kepadatan fitoplankton pada stasiun 4 dapat disebabkan oleh beberapa faktor, seperti kecerahan, kekeruhan, unsur hara dan aktifitas manusia. Menurut Muchlisin dan sJannah (2012) limbah rumah tangga yangberasal dari aktifitas manusia dapat menyebabkan perairan disekitarnya mengalami kekeruhan yang dapat menghalangi sinar matahari masuk ke perairan, sehingga akan mengganggu proses fotosintesis dari fitoplankton pada perairan disekitar stasiun. Kecerahan di estuari Sungai Mempawah pada stasiun 4 berkisar 15,6 cm.Menurut Akrimi dan Gatot (2002), kecerahan perairan dibawah $100 \mathrm{~cm}$ tergolong tingkat kecerahan rendah.

Kepadatan fitoplankton pada stasiun 3 dan Stasiun 4 didominasi oleh kelas Bacillariophicea yaitu genus Coscinodiscus. Kepadatan genus Coscinodiscus pada stasiun 3 sebanyak 109 Ind/L dan stasiun 4 cukup tinggi sebanyak $76 \mathrm{Ind} / \mathrm{L}$. Tingginya genus Coscinodiscus pada stasiun 3 dan stasiun 4 diduga akibat pengaruh rendah salinitas yang disebabkan oleh masuknya air tawar dari hulu Sungai Mempawah. Pengaruh dari masuknya air tawar yang berasal dari hulu Sungai Mempawah mengakibatkan rata-rata 
salinitas pada stasiun 3 dan stasiun 4 adalah 0\%o. Kraberg et al., (2010), menyatakan bahwa genus Coscinodiscus memiliki kemampuan toleransi terhadap suhu dan salinitas rendah. Genus Coscinodiscus juga memiliki ketahanan terhadap infeksi parasit yang disebabkan oleh limbah (Kühn dan Hofmann, 1998). Melimpahnya genus Coscinodiscus pada suatu perairan patut diwaspadai, karena genus Coscinodiscus dapat memproduksi lendir dalam jumlah banyak yang dapat mengakibatkan terjadinya penyumbatan pada jaringan tubuh pada ikan. Selain itu genus Coscinodiscus juga dapat menyebabkan penyakit pada manusia yaitu penyakit radang kulit (Eno et al., 1997).

\subsubsection{Indeks Keanekaragaman, Indeks Keseragaman dan Indeks Dominansi}

Hasil perhitungan nilai keanekaragaman (H'), keseragaman (E') dan dominansi (C) fitoplankton di estuari Sungai Mempawah dapat dilihat pada Tabel 2 .

Nilai indeks keanekaragaman (H') pada estuari Sungai Mempawah tergolong sedang yaitu berkisar antara 2,687 hingga 2,958. Menururt Krebs (1989) nilai indeks keanekaragaman $\left(\mathrm{H}^{\prime}\right)<3$ tergolong sedang. Indeks keanekaragaman jenis biota pada suatu perairan bernilai $\mathrm{H}^{\prime}<3$ dikatakan keanekaragaman jenis biota dalam kondisi stabil.

Nilai indeks keseragaman (E') di estuari Sungai Mempawah tergolong rendah yaitu berkisar antara 0,298 - 0,4591. Menururt Krebs (1989) nilai indeks keseragaman (E') $<1$ menyatakan bahwa keseragaman fitoplankton di perairan estuari Sungai Mempawah sangat rendah. Menurut Wardhana (2003), bahwa rendahnya nilai indek keseragaman jenis biota pada suatu perairan dikarenakan kekayaan individu yang dimiliki oleh masing-masing spesies pada perairan tersebut sangat jauh berbeda.

Nilai indeks dominansi (C) di estuari

Tabel 2. Indeks Keanekaragaman (H'), Indeks Keseragaman (E') dan Indeks Dominansi (C) di estuari Sungai Mempawah

\begin{tabular}{cccc}
\hline \multirow{2}{*}{ Stasiun } & \multicolumn{3}{c}{ Indeks } \\
\cline { 2 - 4 } & $\mathrm{H}^{\prime}$ & $\mathrm{E}^{\prime}$ & $\mathrm{C}$ \\
\hline 1 & 2,687 & 0,298 & 0,121 \\
2 & 2,764 & 0,356 & 0,094 \\
3 & 2,917 & 0,458 & 0,086 \\
4 & 2,922 & 0,462 & 0,077 \\
5 & 2,958 & 0,459 & 0,083 \\
\hline
\end{tabular}

Tabel 3. Parameter Fisika-Kimia Perairan di Estuari Sungai Mempawah

\begin{tabular}{|c|c|c|c|c|c|c|c|c|}
\hline \multirow{2}{*}{ No } & \multirow{2}{*}{ Parameter } & \multicolumn{5}{|c|}{ Stasiun Pengamatan } & \multirow{2}{*}{$\begin{array}{c}\text { Rata- } \\
\text { rata }\end{array}$} & \multirow{2}{*}{$\begin{array}{c}\text { Baku Mutu } \\
\text { KEPMEN LH }\end{array}$} \\
\hline & & 1 & 2 & 3 & 4 & 5 & & \\
\hline $\mathbf{A}$ & Fisika & & & & & & & No. 51 Tahun 2004 \\
\hline 1 & $\operatorname{Arus}(\mathrm{m} / \mathrm{s})$ & 0,12 & 0,05 & 0,08 & 0,04 & 0,04 & 0,064 & - \\
\hline 2 & Suhu $\left({ }^{\circ} \mathrm{C}\right)$ & 30 & 31,7 & 31 & 29,9 & 28,6 & 30,24 & Alami \\
\hline 3 & Kecerahan $(\mathrm{cm})$ & 51,7 & 22,3 & 22,3 & 15,8 & 13,2 & 25,03 & $>5$ \\
\hline $\mathbf{B}$ & Kimia & & & & & & & \\
\hline 4 & Salinitas (\%o) & 20,7 & 5,17 & 0 & 0 & 0 & 5,168 & Alami \\
\hline 5 & $\mathrm{pH}$ & 8,34 & 8,07 & 7,73 & 7,55 & 7,43 & 7,823 & $7-8,5$ \\
\hline 6 & Nitrat (mg/L) & 0,65 & 0,82 & 1,42 & 1,08 & 0,83 & 0,959 & $>0,008$ \\
\hline 7 & Fosfat (mg/L) & 0,06 & 0,06 & 0,06 & 0,07 & 0,07 & 0,064 & 0,015 \\
\hline 8 & $\mathrm{TSS}(\mathrm{mg} / \mathrm{L})$ & 103 & 36 & 28 & 24,7 & 28,3 & 44 & $20-80 \mathrm{mg} / \mathrm{L}$ \\
\hline 9 & $\operatorname{TDS}(\mathrm{mg} / \mathrm{L})$ & 301 & 158 & 136 & 129 & 95 & 163,8 & - \\
\hline 10 & DO & 4,8 & 4,8 & 5,2 & 5,35 & 5,15 & 5,06 & $>5 \mathrm{mg} / \mathrm{L}$ \\
\hline 11 & $\mathrm{CO} 2$ & 3,03 & 4,87 & 3,08 & 4,89 & 4,76 & 4,125 & $<10$ \\
\hline 12 & Alkalinitas & 0,36 & 0,32 & 0,28 & 0,45 & 0,43 & 0,366 & - \\
\hline
\end{tabular}


Sungai Mempawah tergolong rendah yaitu berkisar 0,077 hingga 0,121 . Nilai indeks dominansi di estuari Sungai Mempawah dapat dikatakan dalam kondisi stabil, karena jenis fitoplankton yang ditemukan di estuari Sungai Mempawah tidak didominasi oleh satu jenis fitoplankton saja, tetapi didominasi juga oleh jenis fitoplankton lain. Hal ini seperti yang dikemukakan oleh Nurhatika et al (2015) jika nilai indeks dominiansi mendekati 0 menunjukkan bahwa tidak ada spesies yang dominan pada perairan tersebut.

\subsubsection{Parameter Fisika-Kimia Perairan di Estuari Sungai Mempawah}

Hasil analisis pengukuran parameter fisika-kimia perairan di estuari Sungai Mempawah dapat dilihat pada Tabel 3.

Hasil pengukuran parameter fisika - kimia perairan di estuari Sungan Mempawah didapatkan kecepatan arus berkisar antara $0,04-0,12 \mathrm{~m} / \mathrm{s}$, suhu air berkisar antara $28,6-31,7^{\circ} \mathrm{C}$, kecerahan air berkisar antar $13,2-51,7 \mathrm{~cm}$, salinitas berkisar antara $0-$ $20,7 \%$, pH berkisar antara 7,43-8,34, TSS berkisar antara $24,7-103 \mathrm{mg} / \mathrm{L}$, TDS berkisar antara $95-301 \mathrm{mg} / \mathrm{L}$, DO berkisar antara 4,8 - 5,35 mg/L, CO2 berkisar antara $3,03-4,89 \mathrm{mg} / \mathrm{L}$ dan alkalinitas berkisar antara $0,28-0,45 \mathrm{mg} / \mathrm{L}$. Hasil pengukuran unsur hara menunjukkan nitrat berkisar antara $0,65-1,42 \mathrm{mg} / \mathrm{L}$, fosfat berkisar antara $0,06-0,07 \mathrm{mg} / \mathrm{L}$ (Tabel 3).

Pada umumnuya parameter fisika - kimia di estuari Sungai Mempawah masih dalam kondisi baik untuk pertumbuhan fitoplankton. Suhu air di estuari Sungai Mempawah berkisar antara 28,7 - 31,7 ${ }^{\circ} \mathrm{C}$. Menurut Aryawati (2007), suhu optimum untuk pertumbuhan fitoplankton pada perairan tropis berkisar antara $25{ }^{\circ} \mathrm{C}$ hingga $32{ }^{\circ} \mathrm{C}$. Hasil pengukuran kecerahan air di estuari Sungai Mempawah tergolong rendah yaitu berkisar antara 13,2 - 51,7 cm. menurut
Thoha (2007), Kecerahan suatu perairan $<30$ $\mathrm{cm}$ dapat mempengaruhi pertumbuhan dari organisme fitoplankton, karena dapat mempengaruhi proses fotosintesis.

Hasil pengukuran oksigen terlarut (DO) di estuari Sungai Mempawah berkisar antara $4,8-5,35 \mathrm{mg} / \mathrm{L}$. Berdasarkan baku mutu KEPMEN LH No. 51 Tahun 2004, Kisaran oksigen terlarut (DO) di estuari Sungai Mempawah masih dalam kondisi baik untuk pertumbuhan fitoplankton. Menurut Barus (2004), sumber oksigen terlarut dalam air berasal dari penyerapan oksigen diudara melalui kontak antara permukaan air dengan udara dan juga beraasal dari proses fotosintesis diperairan.

\subsubsection{Hubungan Kepadatan Fitoplankton dengen Parameter Fisika-Kimia Perairan}

Analisis faktor-faktor yang mempengaruhi kepadatan fitoplankton dilakukan dengan menggunakan uji korelasi antara kepadatan fitoplankton dengan berbagai parameter fisika-kimia perairan seperti suhu, salinitas, $\mathrm{pH}$, kecerahan, arus, nitrat (NO3), fosfat (PO4), TSS, TDS, DO dan CO (Tabel 4).

Berdasarkan hasil analisis korelasi pada Tabel 4 bahwa parameter fisika - kimia perairan yang berkorelasi positif atau berhubungan sangat nyata dengan kepadatan fitoplankton di estuari Sungai Mempawah adalah salinitas dengan koefisien korelasi sebesar 0,894. Semakin tinggi salinitas suatu perairan, maka kepadatan fitoplankton juga meningkat. Salinitas berkorelasi sangat nyata dengan kepadatan fitoplankton terlihat dari hasil pengukuran salinitas dan kepadatan fitoplankton. Salinitas pada stasiun 1 mencapai 20,7 \%o dengan kepadatan fitoplankton pada stasiun 1 sebesar 3391,2 Ind/L, sedangkan salinitas pada stasiun 4 sebesar $0 \%$ dengan kepadatan fitoplankton pada stasiun 4 hanya sebesar 676,9 Ind/L.

Tabel 4. Hasil Analisis Korelasi (Spearmean) Kepadatan Fitoplankton dangan Parameter Fisika-Kimia Perairan Estuari Sungai Mempawah

\begin{tabular}{|c|c|c|c|c|c|c|c|c|c|c|c|c|}
\hline & Arus & Suhu & $\mathrm{pH}$ & Salinitas & Kecerahan & Nitrat & Pospat & TSS & TDS & DO & $\mathrm{CO} 2$ & Alkalinitas \\
\hline $\begin{array}{l}\text { Correlation } \\
\text { Coefficient }\end{array}$ & 0.3 & 0.2 & 0.7 & $.894^{*}$ & 0.4 & $-.900^{*}$ & -0.1 & 0.7 & 0.7 & -0.667 & -0.1 & 0.2 \\
\hline Sig. (2-tailed) & 0.624 & 0.747 & 0.188 & 0.041 & 0.505 & 0.037 & 0.873 & 0.188 & 0.188 & 0.219 & 0.873 & 0.747 \\
\hline $\mathrm{N}$ & 5 & 5 & 5 & 5 & 5 & 5 & 5 & 5 & 5 & 5 & 5 & 5 \\
\hline
\end{tabular}


Parameter fisika - kimia perairan yang berkorelasi negatif atau berlawanan dengan kepadatan fitoplankton di estuari Sungai Mempawah adalah nitrat dengan koefisien korelasi $-0,900$. Semakin tinggi nitrat suatu perairan, maka kepadatan fitoplankton semakin rendah. Nitrat berkorelasi negatif dengan kepadatan fitoplankton terlihat dari hasil pengukuran nitrat dan kepadatan fitoplankton. Dari hasil kandungan nitrat tertinggi yang didapatkan pada stasiun 3 sebesar 1,42 $\mathrm{mg} / \mathrm{L}$ dengan kepadatan fitoplankton sebesar 709 Ind/L, namun dilihat dari kepadatan fitoplankton tertinggi justru pada stasiun 1 dengan kandungan nitrat sebesar $0,65 \mathrm{mg} / \mathrm{L}$. Hal tersebut diduga disebabkan oleh pergerakan arus yang berasal dari hulu Sungai Mempawah mengangkut senyawa nitrat, sehingga kandungan nitrat menyebar keseluruh badan estuari Sungai Mempawah. Menurut Suryati (2017) meningkatnya kandungan nitrat disebabkan oleh limbah nutrien yang berasal dari aktifitas masyarakat yang bermukim disekitar perairan sungai. Parameter fisika-kimia yang lain seperti arus, suhu, $\mathrm{pH}$, kecerahan, fosfat, TSS, TDS, DO, CO2 dan alkalinitas cenderung tidak memperlihatkan hubungan yang nyata terhadap kepadatan fitoplankton.

\section{Kesimpulan}

Berdasarkan hasil yang diperoleh selama penelitian maka dapat di simpulkan sebagai berikut :

1. Komposisi jenis fitoplankton yang ditemukan di perairan estuari Sungai Mempawah pada setiap stasiun pengamatan di paling banyak ditemukan oleh kelas Bacillariophyceae. Kepadatan fitoplankton tertinggi diperoleh pada stasiun 1 yaitu sebesar 3391 Ind/L, sedangkan kepadatan fitoplankton terendah diperoleh pada stasiun 4 yaitu sebesar 677 Ind/L. Keanekaragaman fitoplankton di estuari Sungai Mempawah tergolong sedang dan cenderung didominansi oleh salah satu genus dalam populasi.

2. Kualitas lingkungan perairan di estuari Sungai Mempawah pada setiap stasiun masih dalam kondisi baik untuk kehidupan fitoplankton berdasarkan baku mutu KEPMEN LH No. 51 tahun 2004.

3. Parameter lingkungan salinitas berkorelasi positif dengan kepadatan fitolankton di estuari Sungai Mempawah nilai korelasi salinitas sebesar 0.894, sedangkan nitrat berkorelasi negatif dengan kepadatan fitoplankton nilai korelasi nitrat sebesar -0.900. Parameter fisika-kimia yang lain seperti arus, suhu, $\mathrm{pH}$, kecerahan, fosfat, TSS, TDS, DO, CO2 dan alkalinitas cenderung tidak memperlihatkan hubungan yang nyata terhadap kepadatan fitoplankton.

\section{Daftar Pustaka}

Akrimi and S. Gatot. 2002. Teknik Pengamatan Kualitas Air dan Plankton di Reservat Danau Arang - Arang Jambi. Buletin Teknik Pertanian. 7.

American Publich Health Association (APHA). 2000. Diagnostic and Statistical Manual of Mantal Disorders Fourth Edition Text Revision. DSM-IV-TR. Arlington. VA: American Psychiatruc Association.

Arinardi, O.H., A.B. Sutomo, S.A. Yusuf, Trimaningsih. E. Asnaryanti, dan S.H. Riyono. 1997. Kisaran dan Kelimpahan dan Komposisi Plankton Predominan di Perairan Kawasan Timur Indonesia. Jakarta: Pusat Penelitian dan Pengembangan Oceanografi LIPI.

Aryawati, R. 2007. Kelimpahan Dan Sebaran Fitoplankton Di Perairan Berau, Kalimantan Timur. Tesis. Bogor: Institut Pertanian Bogor.

Barus, T.A. 2004. Pengantar Limnologi Studi Tentang Ekosistem Air Daratan. Medan Universitas Sumatera Utara.

Dianthani, D. 2003. Identifikasi Jenis Plankton di Perairan Muara Badak, Kalimantan Timur. Makalah Falsafah Sains. (PPs 702).

Eno, N.C., R.A. Clark, and W.G. Sanderson. 1997. Non-Native Marine Species in British Waters : A Review and Directory. City Road Peter, Borough: Joint Nature Conservation Committee Monkstone House.

Hadi, A. 2005. Prinsip Pengelolaan Pengambilan Sampel Lingkungan. Jakarta: PT. Gramedia Pustaka Utama.

Kep MENLH. 2004, Keputusan Kantor Menteri Negara Lingkungan Hidup No.Kep 51 / MENLH / I / 2004, Tentang Pedoman Penetapan Baku Mutu Lingkungan.

Kraberg, A., M. Baumann, and C.D. Durselen. 2010. Coastal Phytoplankton: Photo Guide for Northern European Seas. Germany: Verlag Dr. Friedrich Pfeil, Munchen.

Krebs, C.J. 1989. Ecology Methodology, The Experimental Analysis of Distribution and Abundance. New York: Harper and Row Publishers.

Kühn, S.F. and M. Hofmann. 1998. Infection of Coscinodiscus granii by the parasitoid nanoflagellate Pirsonia diadema: III. Effects of turbulence on the incidence of infection, $J$. of Plankton Research. 21(12): 2323-2340 
Minsas, S. 2013. Komposisi dan Kandungan Klorofil-a Fitoplankton Pada Musim Timur dan Barat di Estuari Sungai Peniti, Kalimantan Barat. Tesis. Padang: Program Pasca Sarjana, Fakultas Matematika Dan Ilmu Pengetahuan Alam, Universitas Andalas, Padang.

Muchlisin, A.Z. and R. Jannah. 2012. Komunitas Fitoplankton Di Daerah Estuari Krueng Aceh, Banda Aceh. J. Depik. 1(3) : 189-195.

Nontji, A. 2008. Plankton Laut. Jakarta: LIPI Press.

Nurhatika, D., A. Zulfikar, and S.T. Raza'I. 2015. Struktur Komunitas Fitoplankton Sebagai Bioindikator Perairan Di Pantai Dolpin Desa Teluk Bakau Kabupaten Bintan. Skripsi. Riau: Manajemen Sumberdaya Perairan, Universitas Maritim Raja Ali Haji.

Nybakken, J.W. 1992. Biologi Laut: Suatu Pendekatan Ekologis. Cetakan Ke-2. Jakarta: Gramedia.

Ocean Biogeographic Information System (OBIS). 2011. Lauderia sp, http:// www.iobis.org/mapper/?taxon id=460503. Accessed 26 Juni 2018.

Rahayu, S., R.T. Setyawati, and M. Turnip. 2013. Struktur Komunitas Zooplankton di Muara Sungai Mempawah Kabupaten Pontianak Berdasarkan Pasang Surut Air Laut. $J$. Protobiont. 2(2):49-55.

Reigman. R., M. de Boer, and L. de Senerpont Domis. 1996. Growth of harmful marine algae in multispecies cultures. J. of Plankton Research. 18(10): 1851-1866.

Suryanti, E. 2017. Keragaman Fitoplankton Sebagai Indikator Kualitas Perairan Kampung Gisi, Kecamatan Teluk Bintan, Kabupaten Bintan. Skripsi. Kepulaian Riau: Jurusan Manajemen Sumberdaya Perairan, FKIP, Universitas Maritim Raja Ali Haji.

Thoha, H. 2007. Kelimpahan Plankton di Ekosistem Perairan Teluk Gilimanuk, Taman Nasional, Bali, Jakarta. J. Makara Sains. 11(1): 44-48

Thurman, H.V. 1994. Introduction Oceanography, 7th ed. New York: MacMillan Publishing Company.

Wardhana, W. 2003. Teknik Sampling, Pengametan, dan Analisis Plankton. Jakarta: Balai Pengembangan dan Pengujian Mutu Perikanan.

West, G.S. 1961. Cambridge Botanical Handbook, Myxophyceae, Peridinieae, Bacillarieae, Chlorophyceae, Together With A Brief Summary of the Occurrence and Distribution of Fresh Water, Algae 1. Australia: The University press, Cambridge. 